\title{
Analysis of Public Communication Strategy during the Covid-19 Pandemic
}

\author{
Lenie Okviana ${ }^{1 *}$ Sendi Eka Nanda ${ }^{2}$ Pipit Fitriyah ${ }^{3}$ \\ ${ }^{1,3}$ Faculty of Social and Political Sciences, Universitas SebelasMaret, Surakarta, Indonesia \\ ${ }^{2}$ Universitas Gunadarma, Depok, Indonesia \\ "Corresponding author.Email:lenieokviana@gmail.com
}

\begin{abstract}
During the COVID-19 emergency period, the Joko Widodo (Jokowi)'s administration did not escape from criticism over the speed, strength and, resilience of the government and response to the crisis. This paper aims to analyze the public communication strategy implemented by the Government of Indonesia in handling COVID-19. Using the literature study method that refers to resources available online, this paper presents a theoretical perspective on the Government of Indonesia's public communication strategy in handling COVID19. Based on the theoretical analysis several things can be described. There is an information bias due to the lack of uniformity of understanding about the characteristics of the COVID-19 outbreak among central and regional governments so that information confusion occurs. Management of communication strategies is not carried out effectively, this is seen in several cases of violations of rules by the community because of the lack of knowledge of the messages that have been received. Then social media is used less maximally in disseminating information so that relationship management is not created properly.
\end{abstract}

Keywords: communication strategy, message, relationship management, COVID 19, information, crisis.

\section{INTRODUCTION}

For Mass Emergency COVID-19, Joko Widodo (Jokowi)'s Government does not escape from criticism that judges the speed, effectiveness and, durability of governments and responds to the crisis over crisis will risking trust community against performance system within situation emergency [8].

The government's unpreparedness, especially in terms of communication strategy, is increasing. Indications of unpreparedness were evident from the first and second cases announced, in which the President claimed that the first positive patient was the result of a search of the Ministry of Health. But based on the information from the patient concerned, the hospital (and then the government) knew that he was positive about covid-19 because he was proactive in reporting. Also, while the president did not inform the addresses of the first two patients, the Minister of Health instead announced it to the media.

The government does not always provide adequate information about Covid-19. Of course, this makes public confidence in the government decrease. Public sentiment on government communications during the Covid-19 pandemic was negatively rated. At least two non- governmental organizations (NGOs) give negative assessments: Research, Education, and Economic and Social Information Institute (LP3ES) and Institute for Development of Economics and Finance (INDEF). Lp3ES' negative assessment of government communications related to the Covid-19 pandemic was given as the government issued 37 blunder statements during the Covid-19 pandemic (Mawardi, 2020). While a negative assessment was given by INDEF based on the results of the survey, $66.28 \%$ of the public showed a negative response to the communication conducted by the government, especially the communication conducted by President Joko Widodo and the Minister of Health (Menkes) Terawan [10].

The government's inability of disseminating data has caused panic and misinformation in the community. This has implications to the emergence of a lot of hoaxs information. From January 23 to April 6, 2020, the Ministry of Communication and Informatics (Kemenkominfo) has identified 1,096 covid-19 issues spread through digital platforms (CNN Indonesia, 2020b). The surge in hoaxs has become another virus amid a pandemic. This situation can be dangerous, given that in times of crisis like this, the potential for disruption to the social, economic, and political order of society due to 
uncertainty is very likely to occur massively and quickly [7].

Another public communication problem is the insecurity of some communities, as evidenced by the dissolution of the crowd in various regions. Amid the increasing ness of covid-19 virus transmission, some people are still not disciplined in implementing various policies made by the government one of the social restrictions distancing. Why does the public obey the rules reluctantly so that there is a crowd? How should the government communicate every existing rule to be obeyed?

Currently, the quantity of infected is increasing by 18,129 patients (as of June 3,2020), violations are still plentiful, trust in the government is still bad, and the government has again made the public confused by rolling out the discourse of the new normal stage.

The government's public communication system related to COVID-19 is considered weak and overlapping, resulting in a loose government focus on priority information that should be conveyed to the public [9]. The government can add uncertainty amid a crisis if it does not implement mature and coordinated public communication strategies.

The background description illustrates the serious problem of the way the government communicates with the public during the covid-19 pandemic. Therefore, this paper focuses on the strategy and communication process that needs to be done by the government as a part of efforts to deal with the problem of covid 19.

The author hopes that this paper can make a practical contribution for policymakers to formulate effective and relevant communication strategies based on the Indonesian context. Because effective communication can guide the public, media, health care providers and, other groups, to be able to respond appropriately to outbreak situations and act in line with public health recommendations (and principles) (Reynolds \& Quinn Crouse, 2008)

Given the novelty of the issue that is popular in the mass media that causes the crisis then the importance of analyzing how the communication processes and strategies need to be done by the government during the handling of the covid-19 problem? For aspect communication strategy, how should: Tackling the bias of communication information circulating on social media? Clear and straightforward information delivery techniques in public communication to give rise to trust?

\section{LITERATURE REVIEW}

\subsection{Communication strategies}

Communication strategy can be interpreted as guidance and communication planning and communication management to achieve a goal. To achieve its objectives, the communication strategy must be able to demonstrate how tactically operational it should be. While the approach depends on the time, situation and condition vary.
Furthermore, the understanding of communication strategy according to Rogers in Cangara (2013) is a design created to change human behavior on a large scale through the transfer of new ideas. In this case, clarity communication strategy will be closely related to the objectives that want to be achieved with the consequences (problems) already taken into account, then also concerning the planning of how to achieve some consequences according to the expected results or following the objectives.

Given Giddens's theory in the communication process, it is also possible to examine the position of existing relationships between agencies and forces that focus on conditions in which actors consider they "can do the opposite," and use their communication skills (agencies) and knowledge of communication programs (rules and resources) to improve communication and social capital for advocacy, and effects change. Strategic repositioning of power can increase opportunities for citizens to participate in the creation of information used in government, and create a two-way flow of information. So that individuals can build their resources, otherwise known as communication capital

The purpose of the communication process should also be to improve the transparency of information generated by the agency, including knowledge of its ownership (Fairbanks, Plowman \& Rawlins, 2007). It builds a communicative capacity system. Similarly, communication capacity can be built by fostering collaboration and networks of people involved in reform. Collective action, as a communicative phenomenon, always includes:

(1) identify and connect people who share good public interests,

(2) communicate messages to people and

(3) coordinating, integrating, or synchronizing individual contributions" (Flanigan,

Stohl\&Bimber, 2006, p. 32).

Several techniques that can be used in communication strategies according to Arifin [6]

1. Redundancy Repetition. This technique is related to how to influence the audience by repeating the message to the audience.

2. Canalizing, a technique by understanding and researching the influence of groups on individuals or audiences.

3. Informative, this technique is a form of a message that aims to influence the audience by providing illumination or explanation.

4. Persuasive. Persuasive techniques are affecting by way of persuasion.

5. Educational is a technique that is one of the efforts to influence the audience of the general statements that are issued, can be realized in the form of a message that will contain opinions, facts, and experiences.

6. Coercive is a technique of influencing society by forcing roads. This technique is usually manifested in the form of rules, commandments and, intimidation. 


\subsection{Identify strategic communication messages}

Public relations behavior within the organization is enforced through communication strategies designed to achieve the organization's goals (Hazleton, 1993). Communication strategies are realized in the form of messages that serve as inputs to target audiences located in the environment. This manifestation is a functional result of the communication process which is a process based on symbol analysis.

Hazleton (1993) states that symbols are a real observable part of the communication process. For communication to be effective, symbols or symbol systems must be shared or at least understood by sources and recipients in the communication process.

\subsection{Relationship management theory}

Maintaining relationships is one of the key principles in strategic communication; it is unsurprising that relationship management theory is the main theory in social media research. Under the relationship management framework, the role of strategic communication is to serve as a communication channel between the organization and the community (Ledingham, 2003). According to the theory, strategic communication should serve as a central role between the parties; have management functions that utilize the process of research management, action planning, implementation, and evaluation; identify attitudes, knowledge, behaviors and, public relations; and will be built around the following organizational standards and policies when communicating with the communities. Various types of strategies, such as openness, lightness, dual concern, and avoidance, can be used when maintaining relationships with the public. According to Bruning and Ledingham (2000), this strategic communication strategy is designed to initiate, foster, and maintain mutually beneficial relationships between groups.

Due to the fickle nature of communication, however, the same basic standards must also be maintained and adapted for strategic communication. As practitioners, learning to fully integrate social media into the strategies and standards of the organizations they represent, they also become more aware of their skills needs (Diga \& Kelleher, 2009).

\section{METHODS}

The method used for this article is a literature review. Data collection techniques were used to read and record and process material, to explore several journals, books and documents (both printed and electronic) as well as other sources of data or information deemed relevant to the study.

\section{RESULTS AND DISCUSSIONS}

\subsection{Use Government Communication Processes and Strategies to the Public}

The public communication process conducted by the government is very slow, as described in the background. The government tends to "ignored" the Issue of Covid-19. Although to determine the strategies of good communication, it takes a good communication process as well. Given Giddens's theory in the communication process, it is also possible to examine the position of existing relationships between agencies and forces that focus on conditions in which actors consider they "can do the opposite," and use their communication skills (agencies) and knowledge of communication programs (rules and resources) to improve communication and social capital for advocacy, and effects, change. In this theory, it is said that there is reciprocity between the governments as an actor, in this case President Jokowi who controls the agency, that is, the Ministers, especially the minister of Health to conduct communication skills. It is this lack of communication that is shown when this case arises. It is evident by the compactness of information submitted to the public regarding patients who the first one is contracting covid 19. Then some of the statements that were read by the Minister of Validity dr. Clouded and spokesman So the information received by the public are biased and there is distrust (trust) in the government.

The generality of information and distrust arises because, rules strategic positions of power cannot increase the opportunity for citizens to participate in the creation of information used in government, thus not creating a twoway flow of information. Ideally, Indonesia, which adheres to a democratic system, must create a two-way flow of information. This two-way communication flow is one of the keys to creating a good communication process between the government and the community. The purpose of the communication process should also improve the transparency of information generated by the agency, including knowledge of its ownership (Fairbanks, Plowman \& Rawlins, 2007). Concerning the repositioning of power, the actor must have the power to regulate the agencies (Ministers) so that cross-communication can be avoided. So that it can build good communication capital.

That way communication can be built by fostering collaboration and networks of people involved in reform. Collective action, as a communicative phenomenon, always includes:

(1) identifying and connecting people who share good public interests, in which the president can identify people who can be trusted when his first case arises. Listen to the voices of local governments who hope for swift action in the handler of this case because it relates to a person's life.

(2) communicating the message to people, this second step is not entirely done by the central government, a 
lot of information is covered such as the number of victims at the beginning on the pretext of not wanting to cause panic. Even though the public needs clear information, the lapses add to the panic.

(3) coordinating, integrating, or synchronizing individual contributions" (Flanigan, Stohl\&Bimber, 2006, p. 32). The third process further demonstrates the government's unpreparedness in dealing with the covid-19 pandemic, the lack of coordination of unable to integrate and synchronize the solutions needed.

Concerning strategies several techniques can be used, the central government can take appropriate strategic measures and more comprehensively. Through redundancy techniques by controlling what is done by the local government through one command, the central government can also perform canalizing techniques by looking at the efforts of the programs carried out by each region, the government can perform persuasive techniques if looking at the efforts of local governments if less maximally run the program, the central government can also perform informative and persuasive techniques and always inform the development of covid 19 both domestically and abroad. The central government can perform educational techniques for all Indonesians and can be done repeatedly and continuously, can also perform coercive techniques and contain sanctions in its natural environment, considering that covid-19 transmission is a very massif in Indonesia.

\subsubsection{Message identification}

Communication strategies are realized in the form of messages that serve as inputs to target audiences located in the environment. This manifestation is a functional result of the communication process that is, a process based on the analysis of symbols.

In the context of the Indonesian government, it may be the imperfection of public communication conducted by the Government due to one of them related to the delivery of messages. Especially the rise of information various versions spread on social media, including information that is not confirmed truth aka hoax. Through social media, the public receives a variety of information related to rumors, allegations, speculations about all things related to COVID-19. However, this information should be realized from the beginning by the government while immediately countering by conveying detailed information to the public.

If the message conveyed to the public can be conveyed properly then, prevention and treatment of the Indonesian government over the virus can be done. Clarity officials at the ministerial level to regional heads do not have the same perception and vision about the threat of this virus. Even some government officials think that Indonesia is safe from the virus and others argue differently.

Polarized views and attitudes at this level of government ultimately result in the views and attitudes of a society that becomes divided and fragmented. No wonder that to this day there are still many people who do not comply with the call for social and physical distancing. The message conveyed through the media should produce functional effects, instead of changing causing dysfunctional effects. The public has no similar views and attitudes, so acting alone and this is due to the government's public communication strategy being seen as directionless. No wonder the public believes more about what they believe through the information they receive on social media.

The message conveyed by the COVID-19 Task Force at the National level at all times only announces the number of victims infected with COVID-19, without conveying positive developments that can put the public first. So it results in great fear and mass paranoia at the public level. Furthermore, this has an impact on destructive attitudes and behaviors. Vertically, some residents refused and showed defiance of its policies and government recommendations on tackling covid-19. Horizontally, people transmit distrust and mutual suspicion as seen in cases of expulsion of citizens to health workers living in their territory. So, on a horizontal state, this problem is no longer limited to covid-19 prevention but is already in the phase of the emergence of disharmony and social conflict.

\subsubsection{Relationship management theory}

Under the relationship management framework, the role of strategic communication is to serve as a communication channel between the organization and the community (Ledingham, 2003). According to the theory, strategic communication should serve as a central role between the parties; has a management function that utilizes four processes of research management, action planning, implementation, and evaluation identify attitudes, knowledge, behaviors and, public relations and, will be built around the following standards and policies when communicating with the community. Various types of strategies, such as openness, lightness, dual concern, and avoidance, can be used when maintaining relationships with the public.

Relationship management theory is related to the use of social media. In this case, since January 29, 2020, the Ministry of Health (Kemenkes) has launched a covid-19 special information channel titled Preparedness to Deal with Novel Coronavirus Infection. This channel is integrated on the official website of the Ministry of Health.58The home page view is quite simple and considered as the source of government online information before the outbreak of COVID-19 cases in Indonesia.

Another website that the Ministry of Health also manages is Emerging Infection: The Latest Official Information Media of Emerging Infectious Diseases. According to its manufacturing history, the website was released in 2019 and is dedicated to containing all information relating to endemic, emerging infectious diseases (diseases that have never been or have existed and attacked in large numbers at a rapid time), re-emerging (old diseases that reappear in new clinical forms), as well 
as zoonotic (diseases that emerge from animals and infect humans) that threaten or attack populations in certain regions of even the world. COVID-19 belongs to this category. Meanwhile, the official government-run COVID-19 website was launched on March 18, 2020, and managed by the COVID-19 Handling Task Force Teamafter being criticized by many for the late public information channel that can be referenced.60 This website is expected to be a one-stop source of information regarding the handling of COVID-19 in Indonesia. From here it can be seen that relationship management is not good. Due to information delays and lack of maximum use of social media, communication strategies are poorly judged.

\section{REFERENCES}

[1] Arifin, Anwar, 1994. strategi Komunikasi, Bandung: CV. Amrico.

[2] Cangara, H. Hafied, 2013. Perencanaan dan strategi Komunikasi. Jakarta: PT. Raja GrafindoPersada.

[3] Kay Lewis, Bobbi and Cynthia Nichols "Social Media and Strategic Communication An Examination of Theory and Practice in Communication Research" dalamHoltzhausen, Derina and Ansgar Zerfass (2015). Routledge Hnadbook of Strategic Communication. New York and London: Routledge

[4] Page Werder, Kelly. "A Theoretical Framework for Strategic Communication Messaging” dalamHoltzhausen, Derina and Ansgar Zerfass (2015). Routledge Hnadbook of Strategic Communication. New York and London: Routledge

[5] Riley, Patricia et al. "Good Governance and Strategic Communication: A Communication Capital Approach" dalamHoltzhausen, Derina and Ansgar Zerfass (2015). Routledge Handbook of Strategic Communication. New York and London: Routledge

\section{Website :}

[6] Arifn, D. (2020) Gugustugasluncurkan covid19.go.id [Online]. Badan Nasional dan PenanggulanganBencana. Available at: https://bnpb. go.id/berita/gugus-tugasluncurkan-covid19-go-id

[7] European Commission. (2020) COVID-19: Commission sets out European coordinated response to counter the economic impact of the coronavirus [Online]. European Commission. Available at: https:// ec.europa.eu/commission/presscorner/detail/en/ip_20_459

[8] Huang, Y. H., \&Su, S. H. (2009) 'Determinants of consistent, timely, andactive responses in corporate crises', Public Relations Review, 35[online]. Available at: https://doi.org/10.1016/j.pubrev.2008.09.020

\section{CONCLUSION}

The government became the first agency to be ready under various conditions. This pandemic learned that public communication in terms of process and their strategy still bad. Many failures are shown from the planning stage to the end. The government should be able to come up with a formulation or technique that the author already mentioned. There must be clear coordination in a system. There is no overlap in the division of work, so the flow of information can be clear and the purpose of handling this pandemic can be achieved.

[9] Husna, M. A. (2020) 'Pakarkomunikasi UGM rekomendasikankomunikasipublikpemerintahterkait COVID-19', Tribunnews, 7 April [online]. Available at: https://jogja.tribunnews.com/2020/04/07/ pakar-

komunikasi-ugm-rekomendasikan-komunikasipublikpemerintah-terkait-covid-19

[10]Indraini,A.,"KomunikasiJokowidanTerawanBelepotan Soal Corona?", https://fnance. detik.com/beritaekonomibisnis/d-4966114/komunikasijokowi-dan-terawan

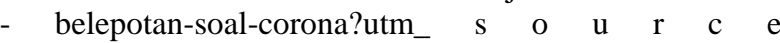
facebook\&utm_campaign=detikcomsocmed\&utm medium =btn\&utm_content=fnance $\&$ fbclid=IwAR2GhbnjI aVYjA7e1jOVH40NgdrDVvm03ykQXIhsSjm2qtknijla Quinn P. (2018) 'Crisis communication in public health emergencies:The limits of 'legal control' and the risks for harmful outcomesin a digital age', Life sciences, society and policy, 14(1) [online].Available at: https://doi.org/10.1186/s40504-018-0067-0 